\title{
Unclasping the Book? Post-Reformation English Catholicism and the Vernacular Bible
}

\author{
Alexandra Walsham
}

In November 1589, news of a provocative act of vandalism reached the ears of the Elizabethan authorities. Robert Goldesborowe, an outspoken recusant who christened his children "in corners" and openly affirmed that all Protestant ministers were knaves, had maliciously defaced an English Bible in three distinct places. One of the passages he chose to mutilate apparently concerned the translation of the Scriptures into the vernacular. Goldesborowe subsequently confessed to this crime of sacrilege "under his owne hand wrytinge."

The details of this intriguing case are unclear, but at first glance it could be interpreted as an example of a committed Catholic layman implicitly defending the principle that the Bible should remain forever encased in the alien language of Latin. Protestant propagandists might have alighted upon it triumphantly as evidence of the extent to which the popish priesthood had brainwashed the laity into believing that there was no need for them to have direct access to God's Word in their mother tongue. Like the case of Thomas Fugall, the Yorkshire vicar investigated for cutting a copy of the Bible with a knife during the reign of Mary I, and the ritual burning of English translations at the time of the Northern Rising in 1569 , they might have seen it as symptomatic of the Church of Rome's innate hatred of Holy Writ itself. ${ }^{2}$

Alexandra Walsham is senior lecturer in history at the University of Exeter. The author would like to thank Margaret Aston, Patrick Collinson, Julia Crick, Elizabeth Ingram, Scott Mandelbrote, and Ethan Shagan for helpful remarks on earlier versions of this essay. She has also benefited from comments made by the members of the seminar audiences in Oxford and Cambridge to whom it was presented.

1 "Informations against Robert Goldesborowe," Public Record Office (PRO), State Papers Domestic (SP Dom.) 12/228/39, November 1589.

${ }^{2}$ See J. Raine, ed., Depositions and Other Ecclesiastical Proceedings from the Courts of Durham, Surtees Society no. 21 (London, 1845), p. 133, though note the reluctance of some of those involved to burn and deface the Bible: pp. 185-86, 188. J. S.

Journal of British Studies 42 (April 2003): 141-166

(C) 2003 by The North American Conference on British Studies.

All rights reserved. 0021-9371/2003/4202-0001\$10.00 
Indeed, at the heart of the rousing democratic rhetoric employed by the early reformers was the claim that the medieval papacy had tyrannically imprisoned the common people in ignorance and superstition by concealing the Bible from their gaze. Polemicists consistently accused the Roman Catholic Church of fighting tooth and nail to preserve a clerical monopoly on the Word. For Martin Luther, this was one of the weak and tottering walls behind which Antichrist sheltered: it was " a wickedly devised fable" that St. Peter alone had been entrusted with the keys to unlock the mysteries of Scripture, a fable designed to hold the masses in blind devotion and humble submission. ${ }^{3}$ By keeping the light of the gospel "under the bushell of a strang toong," declared the Bedfordshire minister Edward Bulkeley, evil friars and prelates had prevented the populace from detecting their gross errors and idolatries. Had the Bible been in "the hands and harts of the people ... that pelting and powling Priest of Rome" could never have maintained his "usurped power" for so many centuries. ${ }^{4}$ According to Edwin Sandys, the papistical hierarchy sought "to hoodwink the world, by conveying the scriptures out of sight." "Instead, Edward Dering alleged, they fed the laity with sugared tales of Bevis of Southampton and Robin Hood, intent on distracting them from discovering the truth. ${ }^{6}$ Closely guarded in cloisters and ecclesiastical libraries, the Bible had been corrupted by the monastic scribes who were its "ordinary Jaylers." 7 But God had preserved his Holy Word ("even," said John Jewel, "as he preserved Daniel in the cave of lions", and "Jonas in the whale's belly") and eventually brought his people out of "Aegypticall darkness" by means of the providential invention of the science of printing. ${ }^{8}$ It was John Foxe who most famously celebrated the press as an instrument of liberation and enlightenment, a divine gift by

Purvis, Tudor Parish Documents of the Diocese of York (Cambridge, 1948), p. 206. Such incidents echo one of the revelations made to Elizabeth Barton, the Maid of Kent, in the reign of Henry VIII: according to one account, an angel commanded her to go to a monk and "byd hym burne the New Testament that he had in Inglyssh." See Thomas Wright, ed., Three Chapters of Letters Relating to the Suppression of the Monasteries, Camden Society, OS 26 (London, 1843), p. 16.

${ }^{3}$ Martin Luther, Address to the Christian Nobility of the German Nation, in Luther's Primary Works, ed. Henry Wace and C. A. Bucheim (London, 1896), pp. 169-71.

${ }^{4}$ Edward Bulkeley, An Answere to Ten Frivolous and Foolish Reasons, Set Downe by the Rhemish Jesuits and Papists (London, 1588), sig. A3r.

${ }^{5}$ Edwin Sandys, The Sermons of Edwin Sandys, D.D., ed. John Ayre, Parker Society (Cambridge, 1842), p. 17.

${ }^{6}$ Edward Dering, A Sparing Restraint, of Many Lavishe Untruths, Which M. Doctor Harding Dothe Chalenge (London, 1568), p. 6.

7 Thomas Cartwright, The Answere to the Preface of the Rhemish Testament (Edinburgh, 1602), p. 113.

${ }^{8}$ John Jewel, The Works of John Jewel, Bishop of Salisbury, ed. John Ayre, 4 vols., Parker Society (Cambridge, 1845-50), 4:763; Bulkeley, Answere, sig. A3v. 
which "the mists of popery" were dispelled and the trumpet of salvation sounded "to all nations and countries under heaven." nourish a myth of Protestant bibliocentricity that lingers on in modern historical thinking, alongside the idea that Roman Catholicism was inherently hostile to a new technology with the capacity to create, almost instantaneously, a priesthood of all believers and readers.

Yet it would be wrong to allow these assumptions to color our understanding of Robert Goldesborowe's iconoclastic attack upon a book that more than any other became an emblem of the English Reformation. For it occurred some seven years after the Catholic community had acquired its own translation of the New Testament, based on the Vulgate but "diligently conferred" with the original Greek. Published in Rheims in 1582, it was prepared at the behest of Cardinal William Allen by Gregory Martin, professor of Hebrew at the Douai seminary. Although completed at around the same time, the two large tomes of the Old Testament were not to appear until 1609-10, when funds became available to defray the immense cost of printing them. ${ }^{10}$ Reassessed in this light, the incident in 1589 takes on different significance: it highlights the fact that by the mid-Elizabethan period the battle for the vernacular Bible had been displaced by a debate about the politics of translation. The issue at stake was no longer whether it was permissible to translate the Scriptures but which version most accurately captured the true meaning and purpose of the Holy Spirit. Perhaps Robert Goldesborowe would have defended his actions in the same way as the group of papists who entered a Berkshire church in 1601-2 and "rent and scattered" the Bible chained to the lectern, leaving behind a letter in which they declared that since the volume was "false" and "hereticall" therefore "To cutt and mangle it is no damnation." 11

The aim of this essay is to reexamine the decision of the English Catholic leaders to translate the Bible into English and to assess the implications that the mass dissemination of Scripture had for a church struggling against persecution and proscription. It seeks to extricate the subject from the distorting polemical straitjacket in which it has so often been constrained and to use it to probe both Catholic and Protestant attitudes toward manuscript, print, and the spoken word in a context in which the

${ }^{9}$ John Foxe, Acts and Monuments, ed. S. R. Cattley, 8 vols. (London, 1853-59), 3 : $718-22$.

${ }^{10}$ The New Testament of Jesus Christ, Translated Faithfully into English, Out of the Authentical Latin (Rheims, 1582); and The Holie Bible Faithfully Translated into English, Out of the Authentical Latin (Douai, 1609-10).

${ }^{11}$ Cited in Pauline Croft, "Libels, Popular Literacy and Public Opinion in Early Modern England," Historical Research 68 (1995): 266-85, 281. 
conditions of communication were rapidly and irrevocably changing. The Bible is an apt focus for discussion of this cluster of themes because the text itself was in some senses a symbol of an earlier shift from memory to written record: although encryption had always been critical to the sacred status of the Hebrew Scriptures, the enshrining of Judeo-Christian truth in a canon of sacred books toward the end of second century A.D. was partly a by-product of an oral culture gradually being infiltrated by the authority of writing.

$$
* \quad * \quad *
$$

The traditional narrative of the making of the vernacular Bible in England has been a triumphalist Protestant one. Absorbing the commonplaces of John Foxe's Acts and Monuments, historians have tended to trace a line from the partial translations and paraphrases of Scripture made in Anglo-Saxon times, through the two Lollard renderings of the Vulgate prepared in the late fourteenth century, to the appearance of William Tyndale's New Testament in 1525. From there, the story is carried forward to the various Henrician editions of the text-Coverdale's of 1535 , the Matthew translation of 1537 , and the Great Bible of 1539, socalled because of its size. The next major landmark is the popular Genevan version, first issued in full in 1560, and noted for its conspicuously Calvinist and anti-Catholic annotations. The work of William Whittingham and other Marian exiles, this was a portable book designed for everyday use. Its chief rival was the official edition of the Elizabethan church, a committee effort generally known as Bishops' Bible, which appeared in 1568. The chronicle culminates with the publication of the Authorized Version in 1611, a masterpiece of majestic, resonant prose. ${ }^{12}$

For many such commentators, the advent of the Scriptures in the vernacular is also a crucial chapter in the emergence of the English language. ${ }^{13}$ It both reflected and reinforced a growing respect for the maternal tongue, which eclipsed the earlier view that it was far too vulgar and barbarous to be a worthy vehicle for divine revelation. Learned exaltation of Latin, Hebrew, and Greek slowly gave way to a new pride in English that was intimately linked with the growth of national identity and historical consciousness. In the process Catholic opposition to Bible translation came to be regarded as unpatriotic: in 1657 Peter Heylyn would accuse

${ }^{12}$ For typical surveys, see Craig R. Thompson, The Bible in English, 1525-1611 (Charlottesville, Va., 1958); F. F. Bruce, The English Bible: A History of Translation (London, 1961); A. C. Partridge, English Biblical Translation (London, 1973); Gerald Hammond, The Making of the English Bible (Manchester, 1982); Edwin Robertson, Makers of the English Bible (Cambridge, 1990).

${ }^{13}$ R. F. Jones, The Triumph of the English Language (London, 1953). 
the papists of claiming that "the heavenly treasure" and "excellent wine" of God's word was polluted by being committed to the "rotten vessels" and "musty bottles" of "the usual Languages of the common people." 14 The rendering of Scripture in the vernacular not only played an important part in erecting ethnic barriers and eroding the foundations of Christian unity in Europe, it also contributed to the onward march of confessionalization. ${ }^{15}$

Within this narrative, the appearance of the Douai-Rheims Bible has often been presented as something of an aberration, a mere footnote to the tale of the heroic Protestant translators who championed the dispersal of Scripture to the thirsty masses. For Henry Cotton, archdeacon of Cashel, writing in 1855, it in no way disguised the unrelenting "animus of the highest officer[s] of the Church of Rome" to free Bible-reading from the Middle Ages through to the mid-nineteenth century. ${ }^{16}$ This tendency to see it as an essentially defensive and negative measure has persisted, despite James G. Carleton's strenuous attempt to demonstrate the extent to which it silently influenced the King James translation. ${ }^{17}$ In Gerald Hammond's survey of 1982, it is presented as a "mighty concession" to fifty years of Reformation polemic and disparaged, rather unfairly, for its "undeniable dependence", on earlier Protestant versions. ${ }^{18}$ Nor has the Rheims New Testament won much praise from critics for its literary qualities: for David Lawton it is "horribly wooden, literal and unidiomatic," while Hammond insists that "a decolloquialising of the Bible", is one of its chief characteristics. ${ }^{19}$

Such statements do contain a grain of truth - the preface defended the distinctly Latinate tone of the text, saying "we presume not in hard places to mollifie the speaches or phrases, but religiously keepe them word for word, and point for point, for feare of missing, or restraining the sense of the holy Ghost to our phantasie." ${ }^{20}$ But they also betray more than a faint echo of the barrage of accusations leveled at Gregory Martin and his collaborators by contemporary Protestant writers. The refutation of the "Rhemists translation"' was undertaken by some of the

${ }^{14}$ Peter Heylyn, The Way and Manner of the Reformation of the Church of England Declared and Justified (London, 1657), p. 70.

${ }^{15}$ See, on this point, Elizabeth Eisenstein, The Printing Press as an Agent of Change (Cambridge, 1979), pp. 359, 702.

${ }^{16}$ Henry Cotton, Rhemes and Doway: An Attempt to Show What Has Been Done by Roman Catholics for the Diffusion of the Holy Scriptures in English (Oxford, 1855), p. 9. 1902).

${ }^{17}$ James G. Carleton, The Part of Rheims in the Making of the English Bible (Oxford,

${ }^{18}$ Hammond, Making, p. 158.

${ }^{19}$ David Lawton, Faith, Text and History: The Bible in English (Hemel Hempstead, 1990), p. 55; Hammond, Making, p. 161.

${ }^{20}$ New Testament, preface, sig. c3v, and see also sig. b2r. 
outstanding theologians of the age, William Fulke, John Rainolds, and William Whitaker among them, and Sir Francis Walsingham promised the disgraced Presbyterian leader Thomas Cartwright $£ 100$ a year to produce a comprehensive refutation of the marginal notes, suggesting that it might make "an overture for your further favour." ${ }^{21}$ Condemning the Catholics' decision to base their translation on the "myrie puddels" of the Vulgate, these divines castigated their adversaries for failing to return ad fontes to the clear fountain of the Greek, ridiculing the claim that the Latin texts used by St. Jerome were actually purer than those that predated them. ${ }^{22}$ They also slated the mercenary motives of the papists in " "aping" the efforts of Protestant ministers "for their grand Masters advantage" ${ }^{23}$ and denounced them for deliberate obfuscation. Forced to abandon their policy of outlawing lay access to the Bible in the vernacular, they now sought to achieve the same end by clogging it with arcane and unintelligible terms. This strategy, said George Wither, was "fraudulently framed to make poore men thinke the Scriptures to be more obscure and darke ... than they are" and so deter them "from taking paines to read them": it was framed "to strike simple persons in a maze." 24 Their "unsavoury silly Annotations" likewise "cast mists" before the eyes of the faithful. According to Fulke, these were "stings, to make way for the poyson to enter." "'How can we but kindle," asked the warden of Winchester, Thomas Bilson, "when we see you fray the people of God from the sweete and wholesome foode of their souls, and delude them with your huskes and hogwash?" ${ }^{25}$ In short, a Bible thus

${ }^{21}$ For a survey of the controversy, see Peter Milward, Religious Controversies of the Elizabethan Age: A Survey of Printed Sources (London, 1978), pp. 46-50. William Fulke, The Text of the New Testament of Jesus Christ, Translated Out of the Vulgar Latine by the Papists of the Traiterous Seminarie at Rhemes (London, 1589); John Rainolds, Six Conclusions Touching the Holy Scripture and the Church (London, 1584); William Whitaker, Ad Nicolai Sanderi Demonstrationes Quadraginta (London, 1583), and An Answere to a Certeine Booke, Written by M. William Rainolds (Cambridge, 1585). For Cartwright, see Sir Francis Walsingham to Thomas Cartwright, PRO, SP Dom. 12/154/48, 5 July 1582. His Answere to the Preface of the Rhemish Testament appeared a year before his death in 1603, but the more comprehensive A Confutation of the Rhemists Translations, Glosses and Annotations was only published in Leiden in 1618.

${ }^{22}$ Quotation from Cartwright, Answere, p. 108. This was the main theme of Bulkeley's Answere.

${ }^{23}$ Bulkeley, Answere, sig. A3v; Richard Bernard, Rhemes against Rome (London, 1626), p. 47.

${ }^{24}$ George Wither, A View of the Marginal Notes of the Popish Testament (London, [1588]), sig. A3r. See also the allegations made in the preface to the Authorized Version of 1611: in Records of the English Bible, ed. Alfred W. Pollard (Oxford, 1911), pp. $375-76$.

${ }^{25}$ Cartwright, Confutation, sig. A4r; Fulke, Text, sig. A2r; Thomas Bilson, The True Difference between Christian Subjection and Unchristian Rebellion (London, 1585), p. 394. 
translated was "as it were un-translated." Despite Rome's claim to have unlocked "the Lords librarie,' the book of God's Word remained tightly clasped and sealed. The Catholic reader was still not allowed "to use his owne eyes without the Popes spectacles.' ${ }^{26}$ The Rheims New Testament did not represent a true reversal of the diabolical policy of suppressing the Bible; on the contrary, it embodied the resurrection of it in a new and more insidious guise.

$$
* \quad * \quad *
$$

Recent work, however, has done much to unsettle the impression of unremitting Catholic hostility to the vernacular Scriptures conveyed by both contemporary and twentieth-century writers. It has shown that attitudes toward this enterprise were far more diverse and fluid than Protestant polemicists implied. The late medieval church was not marked by a monolithic or definitive ban on Bible translation, but by considerable scope for local initiative-by a degree of permissiveness mingled in practice with much distrust and anxiety. ${ }^{27}$ There were notable prohibitions, such as the canon issued by the Synod of Toulouse in 1229, which made it illegal for the laity to possess copies of the Scriptures; the edict of Pope Gregory XI of 1375, which forbade religious books in the vulgar tongue; and the mandate of the archbishop of Mainz, Berthold von Henneberg, which condemned German translations in 1485, on the grounds that they perverted Holy Writ. The conciliarist Jean Gerson was so convinced of their evils that he sponsored a formal proposal for their proscription at the Council of Constance in 1415, though this never became a decree. ${ }^{28}$ But when Innocent III wrote to the bishop of Metz in 1199 regarding some secret conventicles that had taken place in his diocese involving unauthorized readings of the Gospels, Psalms, and letters of St. Paul in French, his real concern seems to have been not with translations of the Scriptures as such, but with the way that they enabled the laity to usurp the clerical office of preaching. ${ }^{29}$

The advent and spread of popular heresy undoubtedly did much to sig. a1r.

${ }^{26}$ Cartwright, Answere, pp. 189, 139, respectively; Bernard, Rhemes against Rome,

${ }^{27}$ See esp. the discussion in Alister McGrath, The Intellectual Origins of the European Reformation (Oxford, 1987), chap. 4; and Jean-François Gilmont, "Conclusion," in The Reformation and the Book, ed. Jean-François Gilmont, trans. Karin Maag (Aldershot, 1998), pp. 470-76.

${ }^{28}$ See Margaret Deanesly, The Lollard Bible and Other Medieval Biblical Versions (Cambridge, 1920), pp. 36, 84, 124, 103, respectively.

${ }^{29}$ See Leonard E. Boyle, "Innocent III and Vernacular Versions of Scripture," in The Bible in the Medieval World: Essays in Memory of Beryl Smalley, ed. Katherine Walsh and Diana Wood, Studies in Church History Subsidia, no. 4 (Oxford, 1985), pp. $97-107$. 
prejudice the issue in the eyes of the authorities. But the fourteenth and fifteenth centuries saw fresh calls for the vernacular Bible from the Brethren of the Common Life, a movement of mystical piety that for the most part managed to escape the taint of heterodoxy. Announcing his intention of preparing a Dutch translation, one author was scandalized by the fact that "it torments some clerks, that men should unbind the secrets of scripture to the common people," countering it by observing that "the apostles of Christ preached and wrote their teaching in all tongues.", 30 With the rise of humanism such ideas acquired considerable respectability, though the project of placing the Bible in the hands of the masses was always in tension with an elitist ethos that privileged reading it in the original Hebrew and Greek. Erasmus's idealistic wish that every plowman would sing it over his furrow and every weaver over his loom inspired the efforts of Jacques Lefèvre D'Etaples in France, who began his translation in $1521 .^{31}$ It also needs to be emphasized that in most parts of Europe the Bible had appeared in the vernacular long before Martin Luther burst upon the scene: no less than eighteen editions of the Scriptures in German were published between 1466 and 1522, the first of four Italian editions was printed in 1471, and the earliest versions in French, Czech, Dutch, and Spanish were issued within a year of each other beginning in $1474 .^{32}$ In 1515 , we find a canon of Lund Cathedral calling for the New Testament to be translated into Danish for the salvation of laypeople who, "unable to understand Latin, cannot read how to live by God's commandments." ${ }^{33}$ In the circles of the Italian spirituali these opinions were frequently articulated, and in an early session of the Council of Trent the whole question was hotly debated. While Archbishop Anthony Filheul of Aix, Cardinal Pacheco, and the Spanish Franciscan Alphonso De Castro held firm against vernacular translations, arguing they would merely engender new heresies, Cardinal Cristoforo

${ }^{30}$ Deanesly, Lollard Bible, chap. 3, esp. pp. 68-88, quotation at p. 74.

${ }^{31}$ Erasmus's famous call to universal Bible reading can be found in his Paraclesis (1516), which was translated into English as An Exhortation to the Diligent Studye of Scripture in 1529, and reprinted in editions of William Tyndale's Newe Testament. On humanism, see Jerry H. Bentley, Humanists and Holy Writ: New Testament Scholarship in the Renaissance (Princeton, N.J., 1983). For Lefèvre D'Etaples, see Lucien Febvre and Henri-Jean Martin, The Coming of the Book: The Impact of Printing, 1450-1800, trans. David Gerard (1976; reprint, London, 1997), p. 295; originally published as L'apparition du livre (Paris, 1958).

${ }^{32}$ See Febvre and Martin, The Coming of the Book, p. 250; David Daniell, William Tyndale: A Biography (New Haven, Conn., 1994), pp. 92-93. The figure for Germany is noted by Bob Scribner in "Heterodoxy, Literacy and Print in the Early German Reformation,' in Heresy and Literacy, 1000-1530, ed. Peter Biller and Anne Hudson (Cambridge, 1994), p. 271.

${ }^{33}$ Cited in Martin D. W. Jones, The Counter Reformation: Religion and Society in Early Modern Europe (Cambridge, 1995), p. 32. 
Madruzzo, Prince-Bishop of Trent, passionately defended them in a speech that concluded: "Let no age, no sex, no condition, no station be prevented from reading Holy Scripture. For the mind of each and every just man is the seat of wisdom; and every good heart that loves Christ can be the receptacle (bibliotheca) where the book of Christ rests." In forbidding translation, he asked, do we not act like the Pharisees, who hold the key to sacred knowledge but will not permit any one else to enter? That the council declined to rule on this burning issue is a point of some importance: it underlines just how intense were the divisions within Catholic ranks on this controversial subject. ${ }^{34}$

In the specific context of England, the picture is also less black and white than it has sometimes been painted. Lollardy certainly served to cement the connection between literacy and heresy, but the fate of Bishop Reginald Pecock of Chichester shows that positions in the mid-fifteenth century were more complex and nuanced than might be assumed. A keen advocate of vernacular instruction as a remedy for popular ignorance and error, Pecock cautiously defended making translations of Scripture available to select sectors of the laity, only to find himself charged with holding Wycliffite views of which he disapproved.$^{35}$ The debate about vernacular translation in Oxford in 1401 likewise proves that many attitudes later identified with Lollard heterodoxy were still neutral in the early years of the movement, and even Archbishop Arundel's notorious Constitution of 1408 permitted lay ownership of English Bibles that had received an episcopal license. ${ }^{36}$ Richard Rex has argued that the sheer number of surviving manuscripts of the Lollard Scriptures suggests that they were not in practice made completely illegal and that more often than not it was the marginal glosses and accompanying commentary rather than the actual text that led to accusations of heretical deviance. ${ }^{37}$ The very fact that William Tyndale approached Bishop Cuthbert Tunstall of

${ }^{34}$ On Trent, see Hubert Jedin, A History of the Council of Trent, trans. Ernest Graf, 2 vols. (London, 1957), 2:67-73, 83; Robert E. McNally, "The Council of Trent and Vernacular Bibles," Theological Studies 27 (1966): 204-27, quotation at 221; Guy Bedouelle, "La débat catholique sur la traduction de la Bible en langue vulgaire," in Théorie et pratique de l'exégèse, ed. Irena Backus and Francis Higman (Geneva, 1990), pp. 39-59.

${ }^{35}$ See Anne Hudson, "Laicus Litteratus: The Paradox of Lollardy," in Heresy and Literacy, 1000-1500, ed. Peter Biller and Anne Hudson (Cambridge, 1994), p. 235; Margaret Aston, "Lollards and Literacy," in her Lollards and Reformers: Images and Literacy in Late Medieval Religion (London, 1984), pp. 193-217; Joseph F. Patrouch, Reginald Pecock (New York, 1970), pp. 84, 89, 94.

${ }^{36}$ Anne Hudson, "The Debate on Bible Translation, Oxford 1401," in her Lollards and Their Books (London, 1985), pp. 67-84. See also Anne Hudson, The Premature Reformation: Wycliffite Texts and Lollard History (Oxford, 1988), chap. 5. The 1408 Constitution is printed in Records, ed. Pollard, pp. 79-81.

${ }^{37}$ Richard Rex, Henry VIII and the English Reformation (Basingstoke, 1993), p. 107. 
London as a potential sponsor for his New Testament implies that he believed the authorities were not entirely inhospitable to the idea of an English Bible. ${ }^{38}$ Sir Thomas More revealed this in his lengthy reply to Tyndale, conceding that the provision of a version in the vernacular was in principle desirable, but at the same time comparing the Lutheran text with poisoned bread from which it was better to abstain than run the risk of dying of "rattes bane." 39 Henrician legislation is a monument both to the plurality of competing opinions on the issue in circulation in the 1530 s and 1540s and to the caution and tergiversation that characterized official policy, most clearly embodied in the 1543 act forbidding private or public reading of Holy Writ by women and the meaner sort of people, but allowing it under controlled conditions for the nobility and gentry. ${ }^{40}$ Under Mary the evangelical views of Cardinal Reginald Pole, close associate of Gasparo Contarini, ensured that the Catholic revival did not include an absolute interdict on translation. Indeed, Pole's legatine synod at Westminster in 1555 agreed to the preparation of an English edition, though it is clear from the sermon he delivered in London on St. Andrew's Day 1557 that Pole believed the sacraments and ceremonies were of equal if not greater importance as "pedagogues of Christ" and conduits of grace. ${ }^{41}$ Such evidence has persuaded Eamon Duffy that "without the goad of the Reformation," the advent of an English New Testament might well have been absorbed into the dominant devotional mood, without the doctrinal uncertainty and conflict that ensued. ${ }^{42}$ Most recently,

${ }^{38}$ Daniell, Tyndale, pp. 83-84.

${ }^{39}$ The Complete Works of St. Thomas More, 12 vols. in 18 pts. (New Haven, Conn., 1963-90), 9:12. On the debate between More and Tyndale, see David Ginsberg, "Ploughboys versus Prelates: Tyndale and More and the Politics of Biblical Translation," Sixteenth Century Journal 19 (1988): 45-61.

${ }^{40}$ See Rex, Henry VIII, chap. 4; 34 and 35 Henry VIII c. 1. In its first draft, the bill would apparently have banned the Bible to the laity in general, as mentioned in a narrative poem ("The disclosinge of the practyse of Stephen Gardyner byschope of Wynchester in the tyme of the moste redoughtyde and excellente prynce Kynge Henry the Eight') written by William Palmer, gentleman-pensioner to the king, in 1547: Trinity College, Cambridge, MS R3.33, fol. 140r. I owe this reference to Alec Ryrie. See also the earlier proclamation of 22 June 1530, in Tudor Royal Proclamations, vol. 1, 1485-1553, ed. Paul L. Hughes and James F. Larkin (New Haven, Conn., 1964), pp. 193-97. The issue is discussed in Susan Wabuda, "The Woman and the Rock: The Controversy on Women and Bible Reading," in Belief and Practice in Reformation England, ed. Susan Wabuda and Caroline Litzenberger (Aldershot, 1998), pp. 40-59.

${ }^{41}$ For the legatine synod, see D. Wilkins, Concilia, 4 vols. (London, 1737), 4:132. On Pole's views, see John Strype, Ecclesiastical Memorials, Relating Chiefly to Religion, 6 vols. in 3 (Oxford, 1822), 3:503-5; Dermot Fenlon, Heresy and Obedience in Tridentine Italy: Cardinal Pole and the Counter Reformation (Cambridge, 1972), esp. pp. 254-55; and Thomas F. Mayer, Reginald Pole: Prince and Prophet (Cambridge, 2000), pp. 246-48.

${ }^{42}$ Eamon Duffy, The Stripping of the Altars: Traditional Religion in England $c$. 1400-1580 (New Haven, Conn. 1992), p. 80. See also the argument of F. A. Gasquet 
Lucy Wooding has interpreted the Douai-Rheims version as essentially a continuation of Marian policy, as a legacy of the uniquely moderate, humanist, and indigenous brand of Catholicism, which, she argues, evolved against the backdrop of the Henrician break with Rome and flourished until it was stifled in the 1570 s by a new climate of confessional rigidity and ideological purity more closely in line with Continental developments. ${ }^{43}$

Certainly, the considerable fluidity of opinion in the early and midsixteenth century deserves recognition. But in reaching the conclusion that the Catholic translation of 1582 was neither a complete about-face nor a bolt from the blue, we must not lose sight of the extent to which circumstances had conspired to politicize the issue. There were voices expressing support for a vernacular Bible not merely from the margins but also within the mainstream of the medieval church. Yet, this cannot disguise the fact that, almost uniquely in Europe, the English lacked an edition in their mother tongue until after 1500. Largely a consequence of the perceived threat of Lollardy, this had the obvious effect of intensifying the desire of laypeople to taste the forbidden fruit of Scripture themselves. Both on the Continent and across the Channel, the rise of Lutheranism served to polarize positions and to make the vernacular Bible both a shibboleth and a catalyst of conflict between the two sides. In retrospect the Council of Trent represented a parting of ways between the spirituali and the zelanti, a repudiation of the legacy of Christian humanism in favor of the neoscholasticism of the Dominicans and Jesuits, a retreat from tendencies that fostered individual exegesis toward a policy of tight ecclesiastical control ${ }^{44}$ Hence the decree of 1546, which reaffirmed the Vulgate as the text for lectures, sermons, and disputations, and insisted upon the need for annotations in all published versions. The Index of 1564 declared that it had been proved by experience that "if the Sacred Books are permitted everywhere and without discrimination in the vernacular, there will by reason of the boldness of men arise therefrom more harm than good," and accordingly charged individual bishops and inquisitors with strictly regulating their perusal, though it should be noted that this represented a softening of the flat prohibition issued by

in "The Pre-Reformation English Bible," in his The Old English Bible and Other Essays (London, 1897). pp. 102-78.

${ }^{43}$ Lucy E. C. Wooding, Rethinking Catholicism in Reformation England (Oxford, 2000), esp. pp. 183-86, 254-55.

${ }_{44}$ Margo Todd, Christian Humanism and the Puritan Social Order (Cambridge, 1987), pp. 206-14. See also Rex, Henry VIII, pp. 130-31; Dominique Julia, "Reading and the Counter Reformation," in A History of Reading in the West, ed. Guglielmo Cavallo and Roger Chartier, trans. Lydia Cochrane (Cambridge, 1999), pp. 238-50. 
the papacy in $1559 .{ }^{45}$ This policy was defended by Fridericus Staphylus, counselor to the Emperor Ferdinand, and by the Polish Cardinal Stanislaus Hosius in two printed treatises translated into English by the Louvain exile Thomas Stapleton in the mid-1560s. It was also energetically upheld by Thomas Harding in the controversy provoked by John Jewel's "Challenge", sermon. ${ }^{46}$

How, then, can we account for the appearance of the Douai-Rheims Bible-of a text that seems so out of touch with the Tridentine decrees? For Lucy Wooding, it is an index of the distance between the priorities of English Catholic thought and the objectives of its European counterpart, a measure of the "insularity" that was its strength, a monument to the "habit of independence" that marked the decades preceding the arrival of the missionary priests - in short, a throwback to a distinctive native species of Catholicism that the seminary movement and the Jesuits combined to eclipse. In what follows, however, I want to offer a variant reading that places more emphasis on the consequences of the dramatic reversal of fortune that the Catholic Church suffered in England after 1559 , as it lost its monopoly status and creatively adapted itself to the condition of being a harassed and hunted minority. ${ }^{47} \mathrm{I}$ shall stress the profound ambivalence about biblical translation that characterized Catholic attitudes both prior to and after 1582, and the sense of unease that accompanied its publication at a time when print technology was effecting fundamental changes in the nature of mass communication. As we shall see, these changes served to accentuate deep-seated differences of opinion about the role of reading and the written word in the transmission of Christianity and about the status of the priesthood vis-à-vis the laity.

As the preface to the Rheims New Testament makes clear, its translation out of Latin was never considered to be anything other than an exceptional and emergency measure. Although it acknowledged that translations had been approved in the past and that even in Wycliffite

${ }^{45}$ The Canons and Decrees of the Council of Trent, ed. and trans. H. J. Schroeder (Rockford, Ill., 1978), pp. 17-20, 274.

${ }^{46}$ Fridericus Staphylus, The Apologie of Fridericus Staphylus . . Intreating of the True and Right Understanding of Holy Scripture. Of the T[r]anslation of the Bible in to the Vulgar Tongue. Of Disagrement in Doctrine amonge the Protestants, trans. Thomas Stapleton (Antwerp, 1565); Stanislaus Hosius, Of the Expresse Worde of God, trans. Thomas Stapleton (Louvain, 1567). Harding's debate with Jewel can be found in Jewel, Works, ed. Ayre, pp. 669-96.

${ }^{47}$ Wooding, Rethinking Catholicism, pp. 179, 227, and see references in n. 43. A somewhat similar line of argument to that presented here is pursued in Cameron A. MacKenzie, The Battle for the Bible in England, 1557-1582 (New York, 2002), chap. 7, which appeared while this article was in press. However, as will become apparent, I 
England they were "not wholly forbidden," it strongly denied publishing the Bible "upon erroneous opinion of necessitie, that the holy Scriptures should alwaies be in our mother tonge." Rather, it was "upon special consideration of the present time, state, and condition of our countrie, unto which, divers thinges are either necessarie, or profitable and medicinable now, that otherwise in the peace of the Church were neither much requisite, nor perchance wholy tolerable." ${ }^{48}$ Persecution and oppression had made imperative what in other contexts would be quite inadmissible. In seeking permission from the papacy for this project in the summer of 1580, Cardinal Allen had insisted that "if ancient discipline still held in England" he would never have dared to petition for an English Bible. Nor did he anticipate that its publication would be a permanent arrangement: once heresy was overthrown and the nation reclaimed to the bosom of Rome, it might be judged convenient to revoke the vernacular Bible and reimpose the Vulgate. ${ }^{49}$

This flexibility and adaptability to the exigency of the times might be seen not as a sign of weakness, but as an adept response to the challenges presented by the entrenchment of Protestantism. It embodied an astute understanding that Catholics would henceforth have to combat the heretics with their own weapon and conduct theological debate according to the rules established by their enemies. An awareness of this dates back to at least 1567, when Thomas Harding and Nicholas Sander wrote to Cardinal Protector Morone that the evils arising from Protestant Bibles might be successfully counteracted by the preparation of a Catholic translation. In a context "seething with heresy," they contended, the best way to persuade people to relinquish corrupt reformed versions was to offer alternative texts of Scripture rendered "in the spirit of the Vulgate." ${ }^{50}$ This was not exactly a new strategy. It had been used with some ingenuity by Jerome Emser as early as 1525 , when he issued an illustrated German New Testament that masqueraded as a Protestant edition but was packed with polemical notes: Johannes Cochlaeus described it as "a special comfort of the Catholics" who could thereby discern Luther's dangerous errors and as a counter to "the evangelical glorying and boasting of the Lutheran fools." ${ }^{51}$ Johan Dietenberger's popular Catholische

cannot endorse his suggestion that the English Catholic leaders adopted a "Protestantlike attitude" toward the vernacular Bible (p. 3). See also pp. 162, 179, 183.

${ }^{48}$ New Testament, preface, sig. a2r-v.

${ }^{49}$ See the crucial letter to Cardinal Sirleto in Rome printed from the Vatican Archives, in J. H. Pollen, "Translating the Bible into English at Rheims," The Month 140 (1922): 146-48.

${ }^{50}$ Letter from the Vatican Archives printed in app. 12 of A. O. Meyer, England and the Catholic Church under Queen Elizabeth, trans. J. R. McKee (London, 1967), pp. 475-78.

${ }^{51}$ Jones, Counter Reformation, p. 55. 
Bibel, first printed in 1534, by contrast, did not seek to disguise its antiheretical stance. In France, René Benoist, a prominent member of the Paris Faculty of Theology, went one step further when he published a vernacular Bible in 1566, shamelessly based on the Geneva translation but purged of Calvinist lies and corruptions: pillaging from the enemy was quite legitimate, he insisted in the preface, in a context of open combat between truth and falsehood. ${ }^{52}$

The Douai-Rheims version similarly sprang from a conviction that profane heretical translations posed a terrible threat to the souls of the inquisitive. While Cardinal Allen would have preferred that the Bible never be translated into "barbarous tongues," he argued that it was better to have a Catholic text "than that men should use a corrupt version to their peril or destruction." ${ }^{53}$ In conjunction with Gregory Martin's Discovery of the Manifold Corruptions of the Holy Scriptures by the Heretickes, it was presented as an antidote to pernicious partisan translations dredged from "the stinking puddles of Geneva lake." ${ }^{54}$ To this extent, there was some truth in Protestant taunts that the book was merely an exercise in damage limitation. "Moved thereunto by the desires of many devout persons" and by compassion for the plight of "our beloved countrie men," Cardinal Allen and his colleagues envisaged it as a missionary tool, a key piece of artillery in the spiritual war in which they were engaged. ${ }^{55}$

This is borne out both by the massive size of the initial print run of around five thousand copies and by the fierce reaction of the Elizabethan authorities. ${ }^{56}$ Cardinal Allen wrote to the Jesuit Alphonsus Agazzari in March 1583 that the Rheims New Testament had made the queen's councillors "quite mad with rage," while a government spy reported that it

${ }^{52}$ For Dietenberger, see Margaret Aston, “The Bishops' Bible Illustrations,', in The Church and the Arts, ed. Diana Wood, Studies in Church History no. 28 (Oxford, 1992), p. 275. For Benoist, see Elizabeth Ingram, "Dressed in Borrowed Robes: The Making and Marketing of the Louvain Bible (1578)," in The Church and the Book, ed. R. N. Swanson, Studies in Church History no. 38 (Woodbridge, in press).

${ }^{53}$ Letter of Cardinal Allen to Dr. Vendeville dated 16 September 1578, trans. in The First and Second Diaries of the English College, Douay (hereafter cited as Douay Diaries), ed. T. F. Knox (London, 1878), p. xli.

${ }^{54}$ Gregory Martin, A Discoverie of the Manifold Corruptions of the Holy Scriptures by the Heretikes of our Daies (Rheims, 1582). Quotation from William Rainolds, A Refutation of Sundry Reprehensions, Cavils and False Sleightes, by which M. Whitaker Laboureth to Deface the Late English Translation (Paris, 1583), p. 292.

${ }^{55}$ New Testament, preface, sig. b2r.

${ }^{56}$ See A. C. Southern, English Recusant Prose, 1559-1582 (London, 1950), p. 235. In June 1581, Cardinal Allen reported to Agazzari that Persons thought that at least four thousand copies were needed: "Expetit P. Rubertus tria vel quatuor millia aut etiam plura ex Testamentis Anglicis, cum illa a multis desiderentur.' Before 1635, the standard size of an edition was around fifteen hundred copies. 
was "as much sought for, of the protesttantes as papistes." ${ }^{57}$ It apparently helped make a convert of Thomas Manby, who went on to enter the Society of Jesus, and it boosted the flagging morale of the Lancashire recusant Andrew Hilton, who implored a friend to send it in February 1584, saying 'I can neither eat, drink nor sleep until I see it.' Under the supervision of her confessor John Mush, the Yorkshire matron Margaret Clitherow read it, along with other spiritual books, in pious imitation of the cloistered religious. ${ }^{58}$ But it is doubtful that this Bible was conceived of primarily as a devotional text for the laity. One of Cardinal Allen's strongest incentives to sponsoring it was an acute sense of the disadvantage Catholic priests were at in direct confrontations with the heretics: while their adversaries had all the key passages of Scripture "at their fingers ends,' he wrote to his friend Dr. Vendeville in September 1578, his own trainees were obliged to translate them from Latin in their heads, with the consequence that they did so "inaccurately, and with unpleasant hesitation." ${ }^{59}$ Replete with a table of controversies and a set of annotations that has been described as "a studied series of deliberate insults," this was a manual for missionaries whose training in the seminaries included mock disputations upon contentious places in Scripture. The aim of these orchestrated debates was to teach novice priests "to spie both the advantages of the truth, and the treacheries and guiles of falshood." Chapters of the Old and New Testament were also read to the assembled students at dinner and supper, after which they sat listening as difficult passages were explicated, "having their Bibles before them, and some their paper and inke." 60 If the Douai-Rheims Bible slavishly followed the Vulgate, this was not only a function of continuing reverence for the Latin text, but because (like the first Lollard version of 1382) it was primarily intended to be an accompanying work of reference, even a crib book for a Catholic clergy seeking to regain the evangelical advantage. ${ }^{61}$

In accordance with the principles enshrined in the Tridentine de-

${ }^{57}$ Douay Diaries, p. 1xx; PRO, SP Dom. 12/168/31.

${ }^{58}$ Henry Foley, Records of the English Province of the Society of Jesus, 7 vols. in 8 (London, 1877-83), 4:603; Unpublished Documents Relating to the English Martyrs, vol. 1, 1584-1603, ed. J. H. Pollen, Catholic Record Society no. 5 (London, 1908), p. 36; John Mush, "A True Report of the Life and Martyrdom of Mrs Margaret Clitherow," in The Troubles of our Catholic Forefathers Related by Themselves, ed. John Morris, 3 vols. (London, 1872-77), 3:393-94.

${ }^{59}$ Douay Diaries, pp. xl-xli. In the same letter Cardinal Allen describes the importance attached to reading and disputing the Scriptures in the training of the missionaries.

${ }^{60}$ Cotton, Doway and Rhemes, p. 15; Gregory Martin, Roma Sancta (1581), ed. George Bruner Parks (Rome, 1969), pp. 115-17. I owe the latter reference to an anonymous reader for this journal.

${ }^{61}$ On the 1382 Lollard translation, see Malcolm Lambert, Medieval Heresy: Popular Movements from the Gregorian Reform to the Reformation (Oxford, 1992), pp. 239-40. 
crees and defended by Counter-Reformation apologists such as Hosius and Staphylus, the translators and later recusant writers remained convinced of the dangers of indiscriminate reading by unlearned laypeople. They stressed the need to preserve the Bible from "abuse and prophanation," to protect the hallowed text from the unwashed hands of the multitude who made it their "table talke" on ale benches and in boats and barges. ${ }^{62}$ Allusion was made to Matt. 7:6 ("Give not that which is holy to dogges: neither cast ye your pearles before swine, lest perhaps they treade them with their feete") - a passage that reminds us that Scripture was seen in the same light as the Sacrament of the Mass itself, a holy mystery that had to be secluded from the multitude by the opaque language of the liturgy ${ }^{63}$ This is neatly encapsulated in an anecdote included in the Jesuit Annual Letter of 1624 recording the sad fate of a puritan cobbler who sat reading the English Bible as he mended shoes and subsequently committed suicide - this was designed to "rebuke the rashness of heretics in handling the sacred pages" and to warn Catholics of the dangers of the same kind of violation. ${ }^{64}$ Shrouded in Latin, the medieval populace had stood before the Scriptures in humility and awe; translated into the vulgar tongue, said Staphylus, they were liable "rashly and roundely [to] set upon it, as if it were Bevis of Hampton or a tale of Robin hoode." ${ }^{65}$ Familiarity with the Bible, it was feared, might breed contempt. Harking back to a time before print had begun to transform books from expensive products of laborious copying into affordable commodities - a time when the physical artifact of Holy Writ itself was popularly supposed to have occult and magical properties ${ }^{66}$ - the laity were encouraged to regard the Scriptures as a precious jewel and treasure. Like a relic or the host itself, the Bible had to be safeguarded from desecration.

Much emphasis was also placed on the need to bridle "the intolerable insolencie of proude, curious, and contenious wittes" who "turne and toss the Scriptures": this was a recipe for rampant heresy and anar-

${ }^{62}$ New Testament, preface, sig. a3r. There were related debates between Catholics and Protestants about the use of the vernacular in the liturgy. Space does not permit a full consideration of these debates here.

${ }^{63}$ Hosius, Of the Expresse Worde of God, fol. 103r-v; Staphylus, Apologie, fols. 4r, $64 \mathrm{v}$. The allusion was implicit rather than explicit in the preface to the New Testament.

${ }^{64}$ Foley, Records of the English Province, 7 (2):1105.

${ }^{65}$ Staphylus, Apologie, fol. 65v. This commonplace can be found in earlier discussions: e.g., Thomas More, The Dialogue concerning Tyndale, in The English Works of Sir Thomas More, ed. W. E. Campbell, 2 vols. (London, 1931), 2:246; and John Standish, A Discourse Wherin Is Debated Whether It Be Expedient That the Scripture Should Be in English for Al Men to Reade That Wyll (London, 1554), sig. A7r-v.

${ }^{66}$ On such beliefs, see Margaret Aston, "Devotional Literacy,'" in her Lollards and Reformers, pp. 106-13. 
chy. Echoing Hosius and Staphylus, Catholic propagandists reiterated the point that the Bible was not for every Tom, Dick, and Harry, warning against the "arrogancie and presumption" of those who manifested an inordinate appetite for knowledge akin to that which had caused Adam and Eve to be expelled from Paradise. The characteristic opacity of Holy Writ was not accidental but conveyed the clear message that God meant many of its secrets to be "far above the reach" of most of mankind. ${ }^{67}$ Scripture was a potent and powerful medicine, but wrongly taken it could be fatal. As the annotation to 2 Cor. 3:6 reminded readers, the letter of the New Testament, no less than the Mosaic Law, could kill. ${ }^{68}$ Interpreted too literally, it could have awful consequences of the kind described by the Dominican Friar Robert Buckenham in a sermon in Cambridge around 1529: "The simple man, when he heareth it in the gospel, 'If thine eye offend thee, pluck it out, and cast it from thee,' may make himself blind, and so fill the world full of beggars." ${ }^{69}$ There was also the fear that some stories in the Old Testament, particularly those concerning Leah, Rachel, and Lot, might give rise to idle and light thoughts in the heads of women and adolescents. ${ }^{70}$ Commending the prudence of the Jews, who had denied access to the Canticles to every person under thirty years of age, Counter-Reformation writers implied that to read the Bible required much learning and a mature understanding of the faith. ${ }^{71}$ In short, laypeople required the expert guidance of the priests God had appointed to be their shepherds and teachers. Like infants, they had to be fed as was "most meete" for their "capacitie and diet," with milk, pap, or with meat that had been predigested thoroughly. ${ }^{72}$ They could not be let loose to consume Scripture unsupervised. This was equivalent to giving a child a knife with which to cut bread for himself-an old commonplace that can be traced back to the fifteenth-century Strasbourg preacher Geiler von Kayserberg. ${ }^{73}$ Just as it was the duty of the laity to receive the sacraments at the hands of the clergy, so too should they accept them as faithful mediators of the mysteries of the Bible. ${ }^{74}$ To do

${ }^{67}$ New Testament, sig. a4r.

${ }^{68}$ Ibid., p. 477.

${ }^{69}$ Foxe, Acts and Monuments, 7:449-50.

${ }^{70}$ Staphylus, Apologie, fol. 76r. See also Thomas Harding, as refuted by John Jewel, Works, 2:674.

${ }^{71}$ New Testament, preface, sig. A4r.

${ }^{72}$ Ibid., sigs. a3v-4r; More, Dialogue concerning Tyndale, p. 244.

${ }^{73}$ Standish, Discourse, sig. A5v. For Geiler von Kayersberg, see Deanesly, Lollard Bible, p. 107.

${ }_{74}$ New Testament, preface, sig. a4r. This, too, was a theme of Geiler von Kayserberg's preaching: see Deanesly, Lollard Bible, p. 107. 
otherwise, declared Martin Becanus in 1619, was to imitate the audacity of Eve in disputing with the serpent in the Garden of Eden. ${ }^{75}$ Staphylus had compared such usurpers with a common craftsman who presumed to displace professional physicians and apothecaries from their shops and dispense potentially harmful drugs himself. ${ }^{76}$ The probability that this inversion of the natural social hierarchy would lead servants to disobey their masters, wives their husbands, and children their parents had been one of the chief themes of John Standish's 1554 tract opposing the vernacular Bible, and these concerns were never far from the surface of discussions that postdated the New Testament translation of $1582 .{ }^{77}$ Indeed, the marginal notes were in many ways intended to counteract the perils of "private judgement" and lay self-instruction. ${ }^{78}$ They were an alternative mechanism for controlling the interpretation of contentious and difficult passages, a typographical substitute for personal contact in a country deprived of an adequate number of pastors. Not until the Jansenists did Catholics actively advocate lay Bible reading and defend the universal availability of the Scriptures - and their views were condemned by the papal bull Unigenitus in $1713 .^{79}$

The importance Counter-Reformation writers attached to lay deference to clerical authority was closely linked with their assumption that Scripture did not contain everything necessary for salvation. The canonical books of the Bible were not the sole source of Christian revelation; the church acted as the custodian of a supplementary deposit of tenets that had never been enshrined in Holy Writ. Whereas many medieval theologians had thought in terms of the mutual coinherence of the written text and unwritten tradition, the polemical battles provoked by the Reformation had intensified a tendency to see them as separate receptacles of sacred truth. By way of reaction against the Protestant doctrine of sola scriptura and its potential to elevate the Bible into a paper pope, the Council of Trent had insisted in 1546 upon the equal parity of apostolic traditions with Scripture. ${ }^{80}$ Tridentine clergyman attached increasing im-

${ }^{75}$ Martinus Becanus, A Treatise of the Judge of Controversies, trans. W. W[right] ([St. Omer], 1619), pp. 61-62.

${ }^{76}$ Staphylus, Apologie, fols. $65 \mathrm{v}-66 \mathrm{r}$.

${ }^{77}$ Standish, Discourse, sig. H3r.

${ }^{78}$ New Testament, preface, sig. b2r-v.

${ }^{79}$ F. J. Crehan, "The Bible in the Roman Catholic Church from Trent to the Present Day," in The Cambridge History of the Bible: The West from the Reformation to the Present Day, ed. S. L. Greenslade (Cambridge, 1963), pp. 222-23.

${ }^{80}$ On Scripture and tradition, see George H. Tavard, Holy Writ or Holy Church: The Crisis of the Protestant Reformation (London, 1959); Yves M-J. Congar, Tradition and Traditions: An Historical and Theological Essay (London, 1966), esp. chaps. 3-5; McGrath, Intellectual Origins, chap. 5. For the Trent decree of 1546, see Canons and Decrees, p. 17. It should be noted that the wording of the decree drew back from insisting 
portance to a corpus of teachings that had been orally transmitted to each generation of the Catholic faithful since the time of St. Peter. They cited key passages such as 2 Thess. 2:15 ("therefore brethren stand and hold the traditions which you have learned, whether it be by word, or by an epistle"'). ${ }^{81}$ The "living voice" of the church was contrasted with the "'inky divinitie", of the heretics, who revered only the "dumb judge," "leaden rule," and "dead letter" of the book and wrested it to serve their purposes like a wax nose. " "The written Text,", declared Thomas Pownde, for instance, "is mute ... uttering nothing to us from the Booke but only the wordes, and not the sense.",83 They also denied that the actual syllables of the Bible were divinely inspired and dictated by the Holy Ghost to the prophets and evangelists. Whereas the logic of the Protestants' arguments pushed them toward the position that textuality was intrinsic to Scripture, Catholics such as Thomas Harding claimed that the Word of God was written in the hearts and minds of men long before it was inscribed on stone, vellum, or parchment. Like Sir Thomas More before him, Harding insisted that it consisted not in ink and paper but in the sense. ${ }^{84}$ In discussing when and why the Lord had ceased to preach viva voce, he and his colleagues rejected the contention that, once Scripture had been pinned down on a two-dimensional page, the need to rely on remembered traditions had passed completely away. Highlighting the role that oral modes had played in the dissemination of the early Hebrew and Christian religions, they repeatedly pointed out that for 2,600 years from Adam to Moses there were no holy books, that it was at least twenty years before the Gospels were penned by the apostles, and that Christ himself had left nothing in writing. ${ }^{85}$ In their

on two independent sources of revelation, but this tendency later became more pronounced.

${ }^{81}$ See New Testament, pp. 559-60 (annotation to 2 Thess. 2:15). See also pp. $413-$ 14 (annotation to Rom. 12:6); p. 454 (annotation to 1 Cor. 11:34); p. 653 (annotation to James 5:17); p. 695 (annotation to Jude 5:9).

82 This was a key issue in the "great controversy", between John Jewel and Thomas Harding in the 1560s: see Jewel, Works, esp. 4:758-59. On the theme of Scripture as a wax nose, see H. C. Porter, "The Nose of Wax: Scripture and the Spirit from Erasmus to Milton,' Transactions of the Royal Historical Society, 5th ser., no. 14 (1964): $155-74$.

83 Thomas Pownde, Sixe Reasons Set Downe to Shew, That It Is No Orderly Way in Controversies of Faith, to Appeale to Be Tryed Onely by Scriptures, reproduced for refutation in Robert Crowley, An Aunswer to Sixe Reasons (London, 1581), sig. A4v.

${ }^{84}$ See Robert Preus, The Inspiration of Scripture: A Study of the Theology of the Seventeenth Century Lutheran Dogmatists (Edinburgh, 1955), esp. pp. 39-73. Harding, in Jewel, Works, 3:240; More, Complete Works, 9:25. See also New Testament, pp. 47677 (annotation to 2 Cor. 3:3).

${ }^{85}$ See John Heigham, The Gagge of the Reformed Gospell ([St. Omer?], 1623), p. 26. For their part, Protestants were obliged to agree; see William Perkins, A Reformed Catholike (Cambridge, 1604), pp. 127-28. 
defense of the sacramental and evangelical quality of speech, they often referred to Rom. 10:17 ("Faith, then, is by hearing: and hearing is by the word of Christ') ${ }^{86}$ Reacting against the impulse to anchor truth to an inert and silent text rather than regard it as an active spiritual presence, they were keen to undermine any suggestion that literacy and reading were prerequisites for entry into heaven.

In the circumstances in which post-Reformation English Catholicism found itself, this attempt to preserve what Walter Ong called the audible "presence of the word," to privilege sound above space as the natural habitat of the Holy Spirit, was more than a little ironic. It was ironic because in yielding a vernacular version of the Scriptures and committing it to the typographical fixity of print, missionary leaders were adopting a medium that had the potential to erode these very same features of medieval Christian experience. The invention of the mechanical press democratized God's Word to a degree that had never been possible in a culture of scribal publication, for all the efficiency we are now encouraged to accord to monastic and other scriptoria. ${ }^{87}$ Even the preface to the Rheims New Testament acknowledged that in earlier centuries there had been no "such easy meanes . . . to disperse . . c copies into the handes of every man, as there now is." ${ }^{88}$ Printed texts arguably effaced the communal aspects of religion at the expense of the individual and ate inexorably away at that clerical monopoly on sacred knowledge that the Church of Rome was so reluctant to relinquish. Yet, to try to restrict readership of the Bible, whether by formal censorship or (as here) by exhortations to exercise a kind of self-denying ordinance, was to demonstrate, as Patrick Collinson has put it, "a Canute-like defiance of the

${ }^{86}$ New Testament, preface, sig. a4r.

${ }^{87}$ Walter J. Ong, The Presence of the Word: Some Prolegomena for Cultural and Religious History (New Haven, Conn., 1967), esp. chaps. 4-5. See also the thoughtful discussions in Eisenstein, Printing Press, chap. 4; François Furet and Jacques Ozouf, Reading and Writing: Literacy in France from Calvin to Jules Ferry (Cambridge, 1982), pp. 59-60, 305-11; and John Bossy, Christianity in the West, 1400-1700 (Oxford, 1985), pp. 97-103. For revisionist assessments of the efficiency of medieval manuscript production, see Richard H. Rouse, "Backgrounds to Print: Aspects of the Manuscript Book in Northern Europe of the Fifteenth Century," in Richard H. Rouse and Mary A. Rouse, Authentic Witnesses: Approaches to Medieval Texts and Manuscripts (Notre Dame, Ind., 1991), pp. 449-66; Paul Saenger, "Colard Mansion and the Evolution of the Printed Book," Library Quarterly 45 (1975): 405-18; Eric H. Reiter, "The Reader as Author of the User-Produced Manuscript: Reading and Rewriting Popular Latin Theology in the Late Middle Ages," Viator: Medieval and Renaissance Studies 27 (1996): 151-69.

${ }^{88}$ New Testament, sig. a3r. 
imperatives of print technology." 89 The new mass medium at least had the capacity to bring the Book to all literate laypeople, while the English language allowed them to bypass the exegetical filter of the priesthood. Together, they did much to undermine the role of clerical middlementhough, as we have seen, the dense undergrowth of annotations appended to each chapter was designed to fulfil this function vicariously. In seeking to use the written word as a partial replacement for personnel in a country where Catholic clergy were scarce and as a surrogate for the sermon and the spoken word, Cardinal Allen and his associates were not pioneers. The idea of an "apostolate of the pen" had medieval precedents: cloistered twelfth-century Carthusian monks had proclaimed the merits of "preaching with their hands" and inflicting wounds on Satan by writing. ${ }^{90}$ But the leaders of the post-Reformation Catholic community were also employing something of a double-edged sword. Just as Henry VIII discovered that the vernacular Bible was not as effective a device for inculcating the creed of obedience as he had initially envisaged, so too did the Counter-Reformation hierarchy have to confront the problem that print could be an agent of autonomy as much as an instrument of authority. ${ }^{91}$

As I have argued elsewhere, the Elizabethan Catholic leaders showed remarkable creativity in utilizing books as "domme preachers" and silent spiritual directors, but they did so at the risk of increasing lay independence. ${ }^{92}$ Indeed, the vast production of devotional and catechetical literature for consumption by this beleaguered community suggests that we need to separate the issue of translating the Scriptures into the vernacular from the wider question of Roman Catholic attitudes to the medium of printing. The two were not intrinsically linked. To echo David Bagchi, we need to set aside the twin-stranded assumption that an ideol-

${ }^{89}$ Patrick Collinson, "The Coherence of the Text: How It Hangeth Together: The Bible in Reformation England,' in The Bible, the Reformation and the Church, ed. W. P. Stephens, Journal for the Study of the New Testament, suppl. ser. no. 105 (Sheffield, 1995), pp. 84-108, p. 98.

${ }^{90}$ Eisenstein, Printing Press, pp. 316, 373.

${ }^{91}$ See Rex, Henry VIII, chap. 4, esp. p. 131; and the discussion in Gillian Brennan, "'Patriotism, Language and Power: English Translations of the Bible, 1520-1580,' History Workshop Journal 27 (1989): 18-36. The possibility that printed Bibles might even render the priesthood redundant had been recognized as early as 1550 in A Godly Dyalogue and Dysputacyon betwene Pyers Plowman and a Popysh Preest in which the latter was made to lament "if these hobbes and rusticals be suffred to be thus busy in readynge of Englysh heresy and to dyspute after this maner wyth us, which are sperytual men, we shalbe fayne to learne some other occupacion or els we are lyke to have but a colde broth" (sig. A8r).

${ }^{92}$ See Alexandra Walsham, “' 'Domme Preachers'? Post-Reformation English Catholicism and the Culture of Print," Past and Present, no. 168 (2000): 72-123. 
ogy that maintained the external clarity of Holy Writ and the priesthood of all believers would accept with alacrity the egalitarian implications of the open book, while one that endorsed the notion of a closed Bible and a priesthood of some believers would naturally reject the press. ${ }^{93}$ Instead, we need to recognize that the marriage of convenience between literacy and heterodoxy and between print and persecution transcended the confessional barrier erected by the Reformation. ${ }^{94}$

It may be, moreover, that the sheer volume of spiritual tracts that issued from clandestine and Continental presses after 1559 was paradoxically a consequence of the very ambivalence of the Catholic hierarchy about making the Bible available in the vulgar tongue. It is certainly striking that the absence of an approved English translation of the Scriptures (and indeed the missal) seems to have stimulated an extraordinary outpouring of vernacular subscriptural and subliturgical literature in early Tudor England. ${ }^{95}$ As David Lawton has remarked in passing, it appears to have fulfilled "a creative function," generating a body of material that offered itself to the populace as "a kind of imaginative substitute" for the sacred text that they were not permitted to handle..$^{96}$ It is also noteworthy that, although Geiler von Kayserberg believed printing a German Bible would be extremely unwise, he expressly advocated the production of works of piety in the language of the simple sort. ${ }^{97}$ And in his influential Apologie, Fridericus Staphylus emphasized that several Catholic bishops had been active in paraphrasing the Scriptures and setting them forth "in the forme of a Breviary or portise, to be read of the clergy by dutie, and of the laitie such as listeth." Together with collections of the sermons and homilies of the church fathers, these should fully satisfy the "desire and appetite" of laypeople who sought to strengthen their faith. ${ }^{98}$ The importance and popularity of texts like the Tridentine primer, which included selected excerpts from the Gospels and Psalms, attests to Roman Catholicism's continuing preference for mediating Scripture to ordinary Catholics through a clerical lens, thereby preserving the sacred mystery that surrounded the Word and protecting it from the indignity of irreverent handling. ${ }^{99}$ If the appearance of the

${ }^{93}$ David V. N. Bagchi, Luther's Earliest Opponents: Catholic Controversialists, 1518-1525 (Minneapolis, 1991), p. 1.

${ }^{94}$ See Alexandra Walsham, "Preaching without Speaking: Script, Print, and Religious Dissent," in The Uses of Script and Print, 1300-1700, ed. Julia Crick and Alexandra Walsham (Cambridge, in press).

${ }^{95}$ See Duffy, Stripping of the Altars, esp. chap. 2.

${ }^{96}$ Lawton, Faith, Text and History, p. 58.

${ }^{97}$ Cited in Scribner, "Heterdoxy, Literacy and Print,", p. 272.

${ }^{98}$ Staphylus, Apologie, fols. 76v-77r.

${ }^{99}$ See A Manuall of Praiers (Calais [English secret press], 1599) and subsequent editions. See A. W. Pollard and G. R. Redgrave, A Short-Title Catalogue of Books Printed 
New Testament in 1582 in no way stemmed the flow of devotional tracts, this was because it was never intended to be the all-sufficient source of inspiration and authority it was in the eyes of fervent Protestants. The Catholic Church did not subscribe to the view that women and men could live, as it were, by the Bible alone.

Even so, this was a text that by 1621 had evolved out of a bulky and cumbersome quarto into a pocket-sized duodecimo- - the format used for portable works of private devotion. The 1633 edition included a series of six fine engravings depicting the evangelists and the Holy Spirit descending upon the apostles at Pentecost-images that brought the book a little closer to a traditional icon. ${ }^{100}$ Against the backdrop of Laudian sponsorship of illustrated Protestant Bibles, these texts helped reignite puritan anxieties about the growth of popish idolatry. ${ }^{101}$ Furthermore, whereas silent reading is often associated with Reformed styles of piety, there are some grounds for thinking that it had certain advantages to a church under the cross. Private perusal probably carried fewer hazards in a context in which the boundary between public recitation of a text and preaching was blurred and in which reading a "popish" book aloud might be construed as a deliberate act of dissent and provocation. ${ }^{102}$ The Protestant Bible, by contrast, may have entered into collective consciousness more often through the ear than through the eye. For many, even most people, it must have been primarily an aural and communal experience. Designed for speaking out loud, the powerful rhythms of the Authorized Version (as of Tyndale's translation before it) were absorbed into everyday speech and memorized and rehearsed by the pious. The future Archbishop James Ussher, for example, learned reading from two blind aunts who knew large portions of the Scriptures by heart. ${ }^{103}$

in England, Scotland, and Ireland and of English Books Printed Abroad, 1475-1640, 2d ed., rev. and enlarged by W. A. Jackson, F. S. Ferguson, and Katharine F. Pantzer, 3 vols. (1976-91), entries 17266 ff.). See also J. M. Blom, The Post-Tridentine English Primer, Catholic Record Society Publications no. 3 (London, 1982), pp. 15-16. In translating scriptural passages, the translator declared that "the direct sense (as it is most requisite) has more bin sought to be observed then any phrases in our language more affected and pleasing."

${ }^{100}$ The New Testament . . . . with Annotations, and Other Helpes (Antwerp, 1621); The New Testament . . . . the Fourth Edition, Enriched with Pictures ([Rouen?], 1633).

${ }^{101}$ See George Henderson, "Bible Illustration in the Age of Laud," Transactions of the Cambridge Bibliographical Society 8 (1982): 173-85. The Root and Branch Petition (December 1640) complained of "the frequent venting of . . popish pictures . . . and the placing of such in Bibles": The Stuart Constitution: Documents and Commentary, ed. J. P. Kenyon (Cambridge, 1986), p. 155. In A Second Beacon Fire by Scintilla (London, 1652), Michael Sparke recalled the brisk trade among Catholics in illustrated English Bibles in the mid-1620s: p. 184.

${ }^{102}$ Compare the remarks of Bossy, Christianity, p. 101. 1686), p. 2.

${ }^{103}$ Richard Parr, The Life of . . J James Usher, Late Arch-Bishop of Armagh (London, 
In their own way, then, Protestants continued to value the oral presence of the Word. In the prefaces to their published works, preachers often stressed the superior benefits of listening to a sermon over reading one imprisoned in the "dead letter" of a text, constantly citing St. Paul's dictum that "Faith cometh by hearing." 104 And as they negotiated the shift from revolutionary sect to institutional church, they too came to find that both printing and the vernacular Scriptures were distinctly mixed blessings. This became apparent as early as 1525 . Luther's rallying cry of "everyman his own bible reader" was rapidly abandoned in the wake of the Peasants' War and the rise of "false brethren" like the Anabaptists who had misconstrued the text to support "fleshly liberty." The translation of the Bible out of Latin seemed to have done nothing so much as open up a Pandora's box of moral decadence and social revolution. And so, as Richard Gawthrop and Gerald Strauss have shown, clerical mediation returned in the guise of the catechism. The Lutheran pastor Caspar Huberinus referred to it approvingly as "our cabala," comparing it with "the secret doctrine of the Jews, kept alive only by word of mouth" and insisting that oral instruction was more efficient than reading, "being more powerfully impressed and more deeply rooted." ${ }^{105}$ Even Calvin believed that God wanted "the bread to be cut for us, the pieces to be put in our mouths, and the chewing to be done for us." 106 Deeming direct engagement with Scripture too dangerous for the average layman, the reformers themselves increasingly sought to filter it through the sieve of marginal glosses and commentaries. Fresh emphasis was placed on approaching the Bible in its original languages, Hebrew and Greek, and on the need for scholarly training to avoid the treacherous pitfalls hidden in Holy Writ. Protestant ministers were effectively reinstated as gatekeepers, a new caste of professional exegetes responsible for controlling access to the sacred books and safeguarding them from misappropria-

${ }^{104}$ See, e.g., John King, Lectures upon Jonas, Delivered at Yorke (Oxford, 1599), sig. *4r. On this subject, see also Arnold Hunt, "The Art of Hearing: Preachers and Their Audiences, 1590-1640" (Ph.D. thesis, University of Cambridge, 2000).

${ }^{105}$ See Richard Gawthrop and Gerald Strauss, "Protestantism and Literacy in Early Modern Germany,' Past and Present, no. 104 (1984): 31-55, esp. 32-43; Gerald Strauss, "Lutheranism and Literacy: A Reassessment," in Religion and Society in Early Modern Europe, ed. Kaspar von Greyerz (London, 1984), pp. 109-20. Huberinus is quoted from Gerald Strauss, Luther's House of Learning: Indoctrination of the Young in the German Reformation (Baltimore, 1978), p. 172.

${ }^{106}$ Quoted in Gilmont, "Conclusion," p. 475, and see pp. 474-76. See also Jean François Gilmont, "Protestant Reformations and Reading," in Cavallo and Chartier, eds., History of Reading, pp. 213-37. Ruth Bottigheimer has argued, however, that the Reformed wing of Protestantism was more inclined than Lutheranism to allow the young to read the Bible in full: 'Bible Reading, 'Bibles' and the Bible for Children in Early Modern England," Past and Present, no. 139 (1993): 66-89. 
tion. ${ }^{107}$ Echoing age-old anxieties, they complained about people who irreverently discussed Scripture in inns and taverns; worried that some members of their congregations might be tempted to "sit at hom[e] with a printed paper, dreaming that will suffice to get faith for salvation"; and denied that they sanctioned "private interpretation" according to the whim of "man's private spirit." 108 This retreat from the heady democratic rhetoric of the early days of the Reformation did not go unnoticed by their confessional enemies. As Staphylus noted tellingly in his Apologie, now it was the Protestants who found themselves obliged "to runne to the refuge of the Catholike church" and take steps to prevent free Bible reading. ${ }^{109}$ There were also those who thought that the Church of England could learn a lesson or two from the Romanists and emulate their "wise jealousy" in censoring the press. In a sermon delivered in 1624 Joseph Hall, later bishop of Exeter, declared that nothing "hath so much power to poison the world": mankind was "highly beholden to that witty citizen of Mentz for his invention of this nimble Art of Impression," but in unleashing a flood of licentious ephemera upon the world it had brought shame and scandal upon the Gospel. "In the times of our forefathers," he observed wistfully, "when every page and line was to pass the leisure and pains of a single pen, books were geason [scarce]; and, if offensive, could not so easily light into many hands to work a speedy mischief." ${ }^{110}$ Writing after the English Revolution, Andrew Marvell satirically depicted the future Anglican prelate Samuel Parker lamenting the effects of "that villainous Engine," the press: "Twas an happy time when all Learning was in Manuscript, and some little Officer . . . did keep the Keys of the Library." ${ }^{111}$ Printing, then, posed a threat to clerical guardianship over God's Word that the reformers first exploited and later rued, if not repudiated.

And so to conclude: we have seen that the debates about vernacular translation and about the merits of oral versus written transmission of the Gospel cut across the pre- and post-Reformation landscape like a series of irregular faults and fissures. In deciding to publish the Rheims

${ }^{107}$ Scribner, "Heterodoxy, Literacy and Print." Mediation of the Bible through clerical hands appears to have been part of early Henrician policy. See the illustrated title page of the 1539 Great Bible, which shows Henry VIII passing down the Bible, verbum $d e i$, to the acclaiming people below via Cromwell and Cranmer.

${ }^{108}$ See Patrick Collinson, The Birthpangs of Protestant England (New York, 1988), p. 107. John Barlow, Hierons Last Fare-Well (London, 1618), sig. A4r; Bernard, Rhemes against Rome, p. 43

${ }^{109}$ Staphylus, Apologie, fol. 44v.

${ }^{110}$ The Works of Joseph Hall, D.D., Successively Bishop of Exeter and Norwich, ed. P. Hall, 12 vols. (Oxford, 1837-39), 8:90-92, 102.

${ }^{111}$ Andrew Marvell, The Rehearsal Transpros'd and the Rehearsal Transpros'd, the Second Part, ed. D. I. B. Smith (1672; reprint, Oxford, 1971), pp. 4-5. 
New Testament, the Elizabethan Catholic leaders were responding to a situation in which an English Bible had become a vital weapon in the struggle to resist the annihilation of the Roman faith, but also reflecting a strand of opinion within the late medieval church that had looked more benignly upon the project of placing the laity in personal contact with the Scriptures in their native tongue. After the Council of Trent this strand of opinion was increasingly confined to the edges: as confessional boundaries hardened Catholicism clung ever more tightly to the much-maligned Vulgate and defended the authority of "unwritten traditions," while Protestantism prided itself on emancipating the masses from the thraldom of Latin with the assistance of the "divine gift" of printing. But the anxieties attendant upon unclasping the Book and disseminating it by means of the mechanical press were shared by key figures on both sides of the ideological divide. Reacting against a medium with the potential to transform physical access to God's Word from the exclusive preserve of the clergy into the common property of an infinite and invisible readership, some began to think that scribal copying and the spoken word might just be safer methods of communicating Holy Writ after all. In the end, to quote John Bossy, perhaps "typography caught up with them all, imposing a Christianity of the text which none ... had originally intended." ${ }^{112}$

${ }^{112}$ Bossy, Christianity, p. 101. 